\title{
Penerapan Model Discovery Learning Meningkatkan Aktivitas Belajar Siswa Sekolah Dasar
}

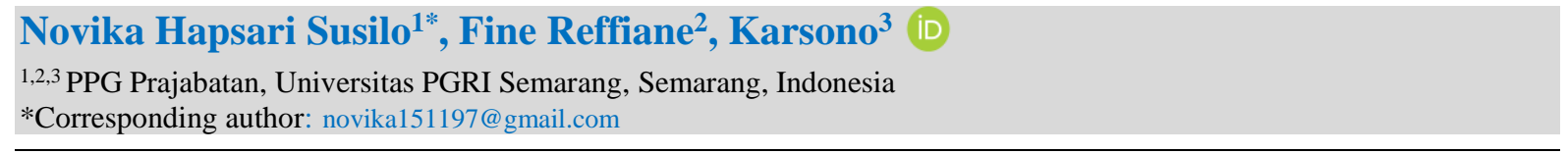

\section{Abstrak}

Pengelolaan sistem informasi administrasi yang baik merupakan faktor penting dalam proses administrasi perpustakaan sekolah. Tujuan dari penelitian ini adalah untuk merancang sistem informasi perpustakaan sekolah berbais web dengan wordpress dan untuk mengimplementasikan sistem yang dirancang. Data-data yang digunakan dikumpulkan dengan menggunakan teknik observasi dan wawancara serta dokumentasi. Jenis metode pengembangan yang digunakan adalah Research and Develompment (R\&D). Model pengembangan yang digunakan adalah model waterfall. Prinsip pendekatan sistem yang diterapkan model ini terdiri dari lima tahap, yaitu analisis, disain, coding, pengujian serta implementasi \& maintenance. Sedangkan platform CMS yang digunakan adalah Wordpress serta software phpMyAdmin sebagai bahasa pemrograman dan MySQL sebagai manajemen basis data (pengelola database). Hasil penelitian menunjukkan bahwa sistem informasi perpustakaan sekolah berbasis web dengan wordpress yang dirancang dinyatakan valid dan praktis untuk dapat digunakan sebagai sistem informasi perpustakaan sekolah. Secara keseluruhan, sistem informasi perpustakaan sekolah berbasis web ini akan mampu memberikan layanan perpustakaan yang lebih baik bagi siswa, guru dan staf. Sehingga keberadaan sistem informasi perpustakaan sekolah berbasis web dengan wordpress memberikan beberapa manfaat dalam proses pelaksanaan layanan perpustakaan.

Kata kunci: Discovery Learning, Aktivitas Belajar, Siswa

\section{Abstract}

This study aims to analyze the application of the Discovery Learning model to improve the learning activities of elementary school students. This research is a Classroom Action Research. The subject of this research is the fourth grade elementary school students with a total of 32 students. The research was carried out in 3 cycles, each cycle consisting of 2 meetings. The data sources in this study were IVC class students, class teachers, and document data. The data collected is qualitative data covering student learning activities and teacher activities, and quantitative data covering student learning outcomes, class averages, and classical learning completeness. Data collection techniques in the form of tests and non-tests which include observation and documentation. Data collection tools in the form of tests and observation sheets (observations). This research is declared successful if student learning activities increase according to predetermined success indicators. The results of the first cycle research showed that student learning activities were $60.36 \%$. With the results obtained, researchers have not been able to meet the indicators of success. Therefore, the researchers made improvements in the second cycle so that the research results could increase. In the second cycle, student learning activities increased to 72.66\%. With the results obtained, researchers have not been able to meet the indicators of success. Therefore, the researchers made improvements in the third cycle so that the research results could increase. In the third cycle, student learning activities increased to $80.28 \%$. Thus, it can be concluded that the Discovery Learning model can improve the learning activities of fourth grade elementary school students.

Keywords: Discovery Learning, Learning activity, Student

\section{INTRODUCTION}

Kurikulum 2013 merupakan suatu kebijakan pemerintah dalam bidang pendidikan, yang diharapkan dapat memberikan Keseimbangan aspek kognitif, aspek afektif, dan aspek psikomotor secara berimbang (Abdulah et al., 2021; Citrawathi et al., 2016). Dengan demikian, melalui implementasi kurikulum 2013 pendidikan diharapkan dapat melaksanakan sarana yang tepat untuk menumbuhkan kreativitas dan berpikir kritis peserta didik. Dalam rangka mewujudkan hal tersebut, maka diperlukan pelaksanaan kurikulum di sekolah lebih memperhatikan proses pembelajaran yang menekankan kegiatan mengamati, menanya, menalar, dan mencoba (Asta et al., 2015; Indraswati et al., 2020). Kurikulum 2013 menekankan pembelajaran untuk siswa SD menggunakan pembelajaran tematik integrative

$\begin{array}{ll}\text { History: } & \\ \text { Received } & \text { : June 28, } 2021 \\ \text { Revised } & \text { : June 30, } 2021 \\ \text { Accepted } & \text { : September, } 2021 \\ \text { Published } & \text { : October 25, } 2021\end{array}$


(Arum \& Wahyudi, 2016; N. A. Estuwardani \& Mustadi, 2015). Pembelajaran tematik integratif merupakan pembelajaran yang memiliki karakteristik yang berpusat pada peserta didik dan memberi pengalaman langsung pada peserta didik (Arum \& Wahyudi, 2016; Norayeni Arista Estuwardani \& Mustadi, 2016). Pembelajaran tematik integratif dapat diimplementasikan melalui: integrasi keterampilan disejumlah mata pelajaran; asimilasi berbagai konten dalam mata pelajaran; integrasi nilai dalam mata pelajaran; dan integrasi pengetahuan dan praktik (Bahar et al., 2019). Implementasi pembelajaran tematik adalah dengan merakit atau menggabungkan sejumlah konsep beberapa mata pelajaran yang berbeda dalam suatu tema, sehingga peserta didik tidak belajar konsep dasar secara parsial (Khoeriyah \& Mawardi, 2018; Ulfah et al., 2019). Dengan demikian pembelajarannya memberikan makna yang utuh kepada peserta didik.

Aktivitas belajar siswa merupakan hal yang sangat penting dan perlu diperhatikan oleh guru sehingga proses belajar mengajar yang ditempuh benar-benar memperoleh hasil yang optimal (Pittariawati, 2020; Subudi, 2021). Seseorang melakukan aktivitas karena didorong oleh adanya faktor-faktor kebutuhan biologis, insting, dan mungkin unsur-unsur kejiwaan yang lain serta adanya pengaruh perkembangan budaya manusia (Arrasyid et al., 2017; Subiyakto et al., 2017). Dalam persoalan ini Skiner lebih cenderung merumuskan dalam bentuk mekanisme stimulus dan respon (Hapsyah et al., 2019; Purwanto, 2017). Mekanisme hubungan stimulus dan respon inilah akan memunculkan suatu aktivitas. Dalam proses belajar mengajar, keaktifan peserta didik merupakan hal yang sangat penting dan perlu diperhatikan oleh guru sehingga proses belajar mengajar yang ditempuh benar-benar memperoleh hasil yang optimal.

Hasil wawancara oleh guru kelas IVC SD Supriyadi melalui WhatsApp dikarenakan masih pandemi maka wawancara dilakukan secara virtual tidak langsung tatap muka, ada beberapa permasalahan yang dihadapi dalam pelaksanaan pembelajaran tematik yang sudah dilakukan nampak penyajian materi pembelajaran tematik tidak terintegrasi antara disiplin ilmu yang digunakan, sehingga pembelajaran yang diberikan mempelajari muatan pelajaran IPA dulu, kemudian Bahasa Indonesia, SBdP, PPKn, dan IPS, yang dibungkus dalam tema tertentu. Pembelajaran belum menggunakan model pembelajaran yang inovatif, masih dominan menggunakan metode ceramah menjelaskan materi kemudian pembahasan soal-soal pada buku BUPENA. Aktivitas belajar siswa rendah dilihat dari dari siswa kurang aktif dalam proses pembelajaran karena pembelajaran masih berpusat pada guru. Dari 32 siswa di kelas IVC, presentase siswa yang aktif sekitar 31,25\% dari 32 siswa artinya hanya 10 siswa yang aktif melakukan aktivitas belajar sisanya 22 siswa tidak aktif melakukan aktivitas belajar. Hal tersebut disebabkan oleh peserta didik merasa jenuh dan tidak fokus selama proses pembelajaran daring. Berdasarkan diskusi peneliti dengan guru kelas IVC, untuk memecahkan masalah pembelajaran tersebut, peneliti menetapkan alternatif tindakan untuk meningkatkan kualitas pembelajaran, yang dapat mendorong siswa untuk lebih aktif dalam pembelajaran dan mendapatkan aktivitas belajar yang maksimal. Maka peneliti menggunakan model pembelajaran inovatif Discovery Learning.

Model Discovery Learning merupakan sebuah model pembelajaran yang berpusat pada peserta didik, guru memberikan kesempatan dan kebebasan kepada peserta didik untuk menemukan, menggali, dan mengkonstruksi pengetahuannya sendiri, sehingga peserta didik dapat lebih mengerti dan mudah memahami materi pembelajaran (Noviyanti et al., 2019; Sahara et al., 2017). Dengan belajar menemukan sendiri, peserta didik akan lebih dapat memahami dan mengingat konsep dan pengetahuan yang dipelajari sendiri, sehingga hasil belajar peserta didik dapat meningkat (Abdulah et al., 2021; Putri et al., 2019). Adapun langkah-langkah pembelajaran dengan Model Discovery Learning yang yakni, 1) memberikan stimulus kepada siswa, 2) mengidentifikasi permasalahan yang relevan dengan bahan pelajaran, merumuskan masalah kemudian menentukan jawaban sementara (hipotesis), 
3) membagi siswa untuk kegiatan berdiskusi, 4) memfasilitasi siswa dalam kegiatan pengumpulan data dan mengolah data, serta 5) mengarahkan siswa untuk menarik kesimpulan (Sunarsih et al., 2020; Wulandari \& Mustadi, 2019).

Penelitian yang relevan dilakukan mengenai upaya peningkatkan aktivitas siswa dalam bentuk penelitian tindakan kelas yang dilaksanakan sebanyak dua siklus secara umum kesimpulan yaitu bahwa penerapan model GI meningkatkan aktivitas dan hasil belajar biologi siswa (Subudi, 2021). Data dalam penelitian ini dianalisis dengan statistik deskriptif. Hasil penelitian menunjukkan bahwa terjadi peningkatan aktivitas dan hasil belajar biologi siswa pada siklus II, skor klasikal rata-rata aktivitas belajar sebesar 14,8 dengan kategori aktif, dan skor klasikal rata-rata hasil belajar sebesar 81,7 dengan kategori baik. Sehingga dapat disimpulkan bahwa penerapan model GI meningkatkan aktivitas dan hasil belajar biologi siswa. Selain itu penelitian yang dilakukan dengan hasil penelitian menunjukkan melalui model Discovery Learning pada siswa dapat meningkatkan aktivitas peserta didik (Astiti et al., 2021). Data hasil belajar dianalisis dengan teknik deskriptif kuantitatif yaitu dengan mencari rata-rata nilai siswa dan ketuntasan belajar. Hasil penelitian menunjukan pada siklus I rata-rata nilai hasil belajar mencapai 67,57 ketuntasan belajar mencapai 66,66\% dengan kriteria cukup dan pada siklus II mengalami peningkatan rata-rata nilai hasil belajar mencapai 79,84 dan ketuntasan belajar mencapai $87,87 \%$ dengan kriteria tinggi. Dapat disimpulkan adanya meningkatkan hasil belajar IPA siswa kelas VI melalui penerapan model pembelajaran discovery learning berbantuan media PowerPoint. Penelitian ini bertujuan untuk menganalisis penerapan model Discovery Learning untuk meningkatkan aktivitas belajar siswa kelas sekolah dasar.

\section{MATERIALS AND METHODS}

Penelitian ini merupakan Penelitian Tindakan Kelas (PTK) yang terdiri dari tiga siklus. Masing-masing siklus mencakup empat tahap kegiatan perencanaan (planning), pelaksanaan tindakan (acting), pengamatan (observing), dan refleksi (reflecting) (Febryanto, 2015; Legiman, 2015). Hasil refleksi setiap siklus digunakan untuk memperbaiki kekurangan dan kelemahan pada siklus sebelumnya. Jika pada siklus I belum memenuhi hasil yang diinginkan, maka perlu adanya tambahan siklus II sebagai perbaikan dan begitu seterusnya. Subjek dari Penelitian Tindakan Kelas (PTK) ini adalah peserta didik kelas IVC SD Supriyadi Semarang dengan total jumlah peserta didik sebanyak 32 orang yang terdiri dari 17 orang laki-laki dan 15 orang perempuan. Penelitian dilakukan di SD Supriyadi Semarang dengan waktu penelitian bulan Maret sampai April 2021 tahun pelajaran 2020/2021. Penelitian ini dilakukan di kelas IVC semester 2 tema 8 daerah tempat tinggalku subtema 2 keunikan tempat tinggalku pembelajaran 1 sampai 6 . Sumber data penelitian diperoleh dari aktivitas belajar siswa kelas IVC SD Supriyadi Semarang dalam proses pembelajaran. Data diperoleh dari sebelum diberikan tindakan PTK dan setelah diberikan tindakan Penelitihan Tindakan Kelas (PTK). Teknik pengumpulan data menggunakan teknik tes dan non tes. Teknik tes digunakan untuk menilai kemampuan siswa yang mencakup pengetahuan dan aktivitas belajar siswa. Penulis melakukan tes untuk mengetahui aktivitas belajar siswa dengan memberikan soal kepada siswa secara online melalui Google Form. Sedangkan teknik non tes digunakan untuk mengobservasi aktivitas belajar siswa melalui lembar observasi.

Data yang diperoleh dari tindakan yang dilakukan dianalisis untuk memastikan bahwa penerapan model Discovery Learning untuk meningkatkan aktivitas belajar. Analisis data dilakukan dalam bentuk beberapa tahap: 1) Menelaah semua data yang diperoleh dari hasil observasi, wawancara, dokumentasi dan catatan lapangan; 2) Mereduksi data yang diperlukan dengan menyeleksi data tindakan hasil belajar siswa, aktivitas siswa, dan aktivitas guru; 3) 
Menyajikan data atau memaparkan data dengan perhitungan frekuensi dan presentasi data; 4) Membahas hasil penelitian; 5) Menyimpulkan hasil penelitian. Sedangkan data yang dikumpulkan berupa angka atau data kuantitatif, cukup dengan menggunakan analisis deskriptif kuantitatif dan sajian visual. Sajian tersebut untuk mengambilkan bahwa dengan tindakan yang dilaksanakan dapat menimbulkan adanya perbaikan, peningkatan dan atau perubahan kearah yang lebih baik jika dibandingkan dengan keadaan sebelumnya. Menggunakan data kualitatif merupakan data yang berupa informasi berbentuk kalimat yang memberi gambaran tentang aktivitas siswa dalam proses pembelajaran tematik tema 8 daerah tempat tinggalku subtema 2 keunikan tempat tinggalku pembelajaran 1 sampai 6 menggunakan model Discovery Learning. Untuk menilai aktivitas belajar siswa dalam pembelajaran menggunakan model pembelajaran Discovery Learning, adapun perhitungan persentase aktivitas belajar siswa dalam mengikuti proses belajar.

\section{RESULTS AND DISCUSSION}

\section{Result}

Penelitian berjudul "Penerapan Model Discovery Learning untuk Meningkatkan Aktivitas Belajar Siswa Tema 8 Daerah Tempat Tinggalku pada Kelas IVC SD Supriyadi Semarang" telah dilaksanakan. Penelitian ini dilaksanakan dalam 3 siklus, yaitu siklus I, siklus II, dan siklus III pada tanggal 21 Maret 2021-20 April 2021 di SD Supriyadi Semarang. Hasil penelitian yang telah dilakukan oleh peneliti pada siklus I, siklus II, siklus III di SD Supriyadi Semarang menunjukkan adanya peningkatan pada aktivitas belajar siswa selama proses pembelajaran. Untuk lebih jelasnya akan dipaparkan pada deskripsi data pelaksanaan tindakan siklus I, siklus II, dan siklus III. Deskripsi data aktivitas belajar siswa siklus 1, deskripsi data pelaksanaan tindakan di siklus I dilaksanakan dua kali pertemuan yaitu pertemuan pertama pada tanggal 29 Maret 2021 dengan muatan pelajaran IPS, Bahasa Indonesia, dan IPA. Siklus I pertemuan kedua dilaksanakan pada tanggal 01 April 2021 dengan muatan pelajaran SBdP, Bahasa Indonesia, dan IPA. Dari pelaksanaan tindakan siklus I diperoleh deskripsi data aktivitas belajar siswa. Deskripsi data pelaksanaan tindakan siklus I yaitu aktivitas belajar siswa selama mengikuti pembelajaran secara klasikal. Data aktivitas belajar siswa menggunakan model Discovery Learning, yaitu pada indikator siswa membaca materi yang akan dipelajari sebesar 60,94\%. Siswa berdiskusi dengan teman sebesar 62,5\%. Siswa bertanya pada guru atau teman sebesar $60,94 \%$. Siswa menyimak penjelasan dari guru sebesar 56,26\%. Siswa membuat catatan tentang materi pelajaran sebesar 64, 07\%. Siswa menanggapi pendapat teman atau guru sebesar 57,82\%. Siswa mengerjakan tes dengan kemampuan sendiri 56,26\%. Siswa bersemangat dalam mengikuti pelajaran sebesar $64,07 \%$. Hasil persentase keseluruhan yang diperoleh dari 8 indikator aktivitas siswa pada siklus I sebesar $60,36 \%$. Hasil observasi aktivitas belajar siswa tersebut belum dapat dikatakan berhasil, karena belum mencapai indikator keberhasilan yang ditetapkan pada aktivitas belajar siswa yaitu $\geq 70 \%$. Hasil observasi terhadap aktivitas belajar siswa selama proses pembelajaran dengan menggunakan model Discovery Learning pada siklus I sebesar 60,36\%. Hasil aktivitas belajar siswa tersebut masih belum mancapai kriteria yang ditetapkan yaitu 70\%. Hal ini disebabkan adanya berbagai kendala saat proses pembelajaran berlangsung. Hasil yang belum mencapai indikator keberhasilan tersebut akan diperbaiki dan ditingkatkan pada siklus II.

Deskripsi data aktivitas belajar siswa siklus II, deskripsi data pelaksanaan tindakan di siklus II dilaksanakan dua kali pertemuan yaitu pertemuan pertama pada tanggal 06 April 2021 dengan muatan pelajaran IPS, PPKn, dan Bahasa Indonesia. Siklus II pertemuan kedua dilaksanakan pada tanggal 08 April 2021 dengan muatan pelajaran Bahasa Indonesia, IPS, dan PPKn. Observasi aktivitas belajar siswa yang dilakukan pada siklus II tampak adanya 
peningkatan. Pada indikator siswa membaca materi yang akan dipelajari sebesar $70,32 \%$. Siswa berdiskusi dengan teman sebesar $71,88 \%$. Siswa bertanya pada guru atau teman sebesar $70,32 \%$. Siswa menyimak penjelasan dari guru sebesar $73,44 \%$. Siswa membuat catatan tentang materi pelajaran sebesar $67,19 \%$. Siswa menanggapi pendapat teman atau guru sebesar $73,44 \%$. Siswa mengerjakan tes dengan kemampuan sendiri 76,57\%. Siswa bersemangat dalam mengikuti pelajaran sebesar 78,13\%. Hasil persentase keseluruhan yang diperoleh dari 8 indikator aktivitas siswa pada siklus II sebesar 72,66\%. Hasil observasi aktivitas belajar siswa tersebut belum dapat dikatakan berhasil, karena masih ada yang belum mencapai indikator keberhasilan yang ditetapkan pada aktivitas belajar siswa yaitu $\geq 70 \%$. Hasil observasi terhadap aktivitas belajar siswa selama proses pembelajaran dengan menggunakan model Discovery Learning pada siklus II sebesar 72,66\%. Hasil aktivitas belajar siswa tersebut sudah mancapai kriteria yang ditetapkan yaitu $70 \%$ tetapi masih ada kekurangan. Hasil yang belum mencapai indikator keberhasilan tersebut akan diperbaiki dan ditingkatkan pada siklus III.

Deskripsi data aktivitas belajar siswa siklus III, deskripsi data pelaksanaan tindakan di siklus III dilaksanakan dua kali pertemuan yaitu pertemuan pertama pada tanggal 15 April 2021 dengan muatan pelajaran SBdP, PPKn, dan Bahasa Indonesia. Siklus III pertemuan kedua dilaksanakan pada tanggal 20 April 2021 dengan muatan pelajaran Bahasa Indonesia, PPKn, dan SBdP. Observasi aktivitas belajar siswa yang dilakukan pada siklus II tampak adanya peningkatan. Pada indikator siswa membaca materi yang akan dipelajari sebesar $75,00 \%$. Siswa berdiskusi dengan teman sebesar 79,69\%. Siswa bertanya pada guru atau teman sebesar 78,13\%. Siswa menyimak penjelasan dari guru sebesar 81,26\%. Siswa membuat catatan tentang materi pelajaran sebesar 79,69\%. Siswa menanggapi pendapat teman atau guru sebesar $82,82 \%$. Siswa mengerjakan tes dengan kemampuan sendiri 81,26\%. Siswa bersemangat dalam mengikuti pelajaran sebesar 84,38\%. Hasil persentase keseluruhan yang diperoleh dari 8 indikator aktivitas siswa pada siklus III sebesar 80,28\%. Hasil observasi aktivitas belajar siswa tersebut sudah dapat dikatakan berhasil, karena sudah mencapai indikator keberhasilan yang ditetapkan pada aktivitas belajar siswa yaitu $\geq 70 \%$. Hasil observasi aktivitas belajar siswa tersebut sudah berhasil terbukti dengan adanya peningkatan aktivitas belajar siswa dari siklus I sebesar 60,36\% meningkat menjadi 72,66\% pada siklus II kemudian meningkat lagi menjadi 80,28 pada siklus III. Peningkatan aktivitas belajar siswa secara klasikal pada siklus I dan siklus II digambarkan pada Gambar 1.

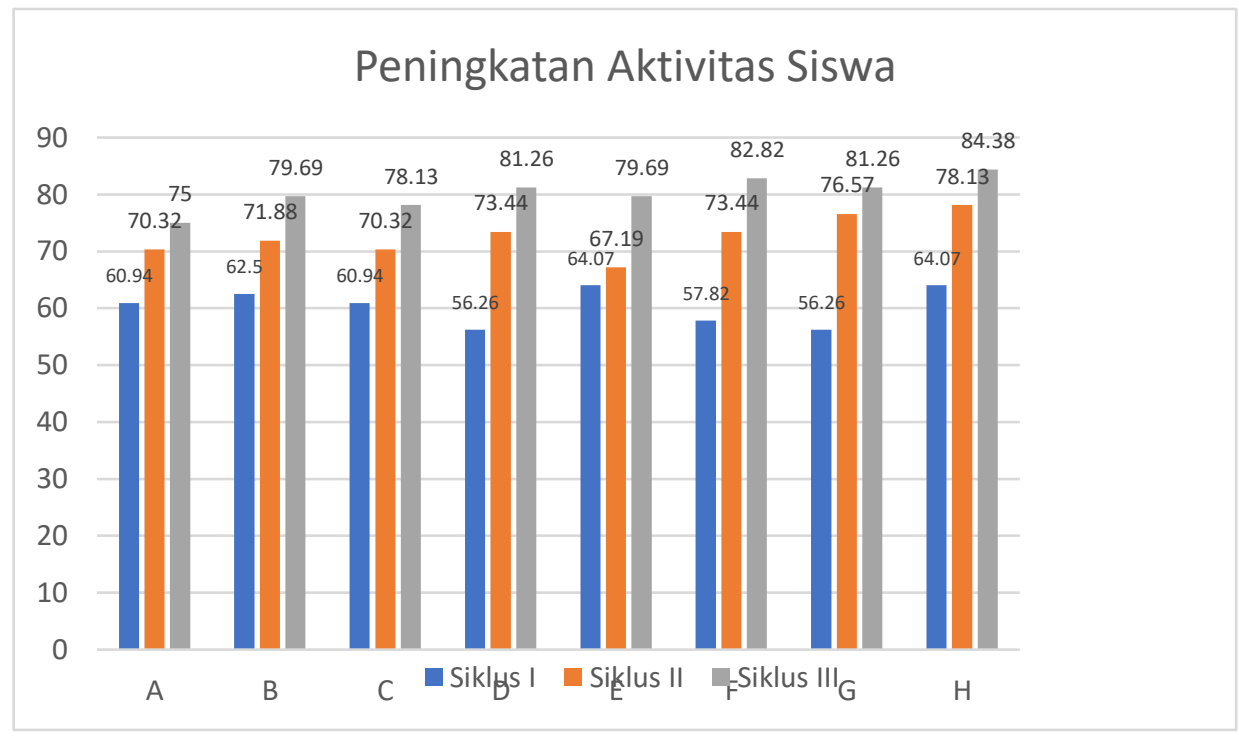

Gambar 1. Diagram Peningkatan Aktivitas Siswa (\%) 


\section{Keterangan :}

A : Siswa membaca materi yang akan dipelajari.

B : Siswa berdiskusi dengan teman.

C : Siswa bertanya pada guru atau teman.

D : Siswa menyimak penjelasan dari guru.

E : Siswa membuat catatan tentang materi pelajaran.

F : Siswa menanggapi pendapat teman atau guru.

$\mathrm{G}$ : Siswa mengerjakan tes dengan kemampuan sendiri.

$\mathrm{H}$ : Siswa bersemangat dalam mengikuti pelajaran.

Hasil observasi terhadap aktivitas belajar siswa selama proses pembelajaran dengan menggunakan model Discovery Learning pada siklus III sebesar 80,28\%. Hasil tersebut menunjukkan adanya peningkatan aktivitas belajar siswa yang pada siklus 1 sebesar $60,36 \%$ serta pada siklus II sebesar $72,66 \%$ meningkat menjadi $80,28 \%$. Peningkatan tersebut disebabkan karena adanya tindakan-tindakan dari guru dengan melihat refleksi hasil dari siklus 1 dan siklus II, yaitu : 1) Meningkatkan aktivitas siswa yang kurang tampak dengan cara memberi penjelasan kepada siswa tentang bagaimana cara menyampaikan pendapat dengan benar kepada siswa, memberi penjelasan kepada siswa tentang makna kerjasama dan bagaimana akibat dari tidak adanya kerjasama dalam suatu kelompok, memberi penjelasan bagaimana cara bertanya yang baik. 2) Guru memberikan bimbingan kepada siswa tentang materi yang dirasa belum dipahami dengan baik.

\section{Pembahasan}

Berdasarkan penelitian yang telah dilakukan, siswa kelas IVC SD Supriyadi Semarang sudah tidak merasa kesulitan lagi dalam mempelajari tema 8 daerah tempat tinggalku subtema 2 keunikan tempat tinggalku pembelajaran 1 sampai 6 . Hal tersebut ditandai dengan adanya antusiasme siswa selama pembelajaran berlangsung dan rata-rata aktivitas belajar yang dicapai siswa setelah diterapkannya model Discovery Learning. Penerapan model Discovery Learning dapat berpengaruh terhadap pembelajaran dengan menerapkan model Discovery Learning yang mengalami peningkatan yang lebih baik dari siklus I, siklus II, dan siklus III. Persentase hasil aktivitas siswa pada siklus I sebesar 60,36\% meningkat pada siklus II menjadi $72,66 \%$ serta meningkat pada siklus III sebesar $80,28 \%$. Peningkatan aktivitas siswa tersebut memiliki makna bahwa model Discovery Learning dapat memotivasi aktivitas belajar siswa selama proses pembelajaran berlangsung. Pada waktu proses pembelajaran, siswa diberi kebebasan untuk beragumentasi. Selain itu, siswa juga saling bekerja sama dan saling membantu antar sesaman teman. Hal tersebut menunjukkan bahwa dalam pembelajaran Discovery Learning menimbulkan interaksi sosial yang baik antar siswa.

Hasil peneltian tindakan kelas yang dilakukan guru dengan menggunakan model Discovery Learning pada tema 8 daerah tempat tinggalku subtema 2 keunikan tempat tinggalku pembelajaran 1 sampai 6 di kelas IVC SD Supriyadi Semarang adalah meningkatnya aktivitas belajar siswa. Aktivitas belajar siswa dapat meningkat apabila memperhatikan karakteristik siswa, karakteristik materi pelajaran, sarana dan prasarana, alokasi waktu pembelajaran, dan kondisi kelas yang dilakukan secara virtual menggunakan Zoom Meeting. Pembelajaran tema 8 daerah tempat tinggalku subtema 2 keunikan tempat tinggalku pembelajaran 1 sampai 6 dengan menerapkan model Discovery Learning dapat meningkatkan performansi guru, apabila guru memperhatikan kondisi siswa dan kelas. Jika guru akan menggunakan model Discovery Learning, maka guru harus mengetahui kemampuan kognitif awal siswa sebelum menerapkan model Discovery Learning. Hal tersebut, supaya dalam pembelajaran guru mudah. Selain itu, guru harus memperhatikan 
kondisi kelas virtual agar pembelajaran yang dilakukan dapat berjalan lancar dan efektif. Guru harus dapat memperhatikan bagaimana kondisi siswa saat mengikuti pembelajaran, guru harus mengerti kapan siswa merasa sangat bersemangat dan kapan siswa merasa jenuh. Aktivitas belajar siswa dapat meningkat dengan menggunakan model Discovery Learning, karena guru memberikan bimbingan, motivasi dan penguatan kepada siswa agar siswa lebih bersemangat dan aktif mengikuti pembelajaran tema 8 daerah tempat tinggalku subtema 2 keunikan tempat tinggalku pembelajaran 1 sampai 6.

Model Discovery Learning merupakan sebuah model pembelajaran yang berpusat pada peserta didik, guru memberikan kesempatan dan kebebasan kepada peserta didik untuk menemukan, menggali, dan mengkonstruksi pengetahuannya sendiri, sehingga peserta didik dapat lebih mengerti dan mudah memahami materi pembelajaran (Noviyanti et al., 2019; Sahara et al., 2017). Dengan belajar menemukan sendiri, peserta didik akan lebih dapat memahami dan mengingat konsep dan pengetahuan yang dipelajari sendiri, sehingga hasil belajar peserta didik dapat meningkat (Abdulah et al., 2021; Putri et al., 2019). Adapun langkah-langkah pembelajaran dengan Model Discovery Learning yang yakni, 1) memberikan stimulus kepada siswa, 2) mengidentifikasi permasalahan yang relevan dengan bahan pelajaran, merumuskan masalah kemudian menentukan jawaban sementara (hipotesis), 3) membagi siswa untuk kegiatan berdiskusi, 4) memfasilitasi siswa dalam kegiatan pengumpulan data dan mengolah data, serta 5) mengarahkan siswa untuk menarik kesimpulan (Sunarsih et al., 2020; Wulandari \& Mustadi, 2019). Menggunakan model Discovery Learning, guru tidak hanya harus mengerti tentang pengertian model Discovery Learning, bagaimana langkah-langkahnya, bagaimana karakteristiknya, tetapi guru juga harus dapat menyesuaikan antara karaktersitik siswa, karakteristik materi pelajaran, sarana dan prasarana, alokasi waktu pembelajaran, dan kondisi kelas untuk mendukung keefektifan pelaksanaan pembelajaran tematik dengan menggunakan model Discovery Learning.

\section{CONCLUSION}

Peneliti dapat menyimpulkan bahwa penerapan model Discovery Learning dapat meningkatkan aktivitas belajar siswa kelas IVC SD Supriyadi Semarang pada pembelajaran tema 8 daerah tempat tinggalku subtema 2 keunikan tempat tinggalku pembelajaran 1 sampai 6. Hasil yang mendukung pernyataan ini yaitu dari hasil observasi terhadap aktivitas belajar siswa selama pembelajaran, dapat diketahui bahwa aktivitas belajar siswa mengalami peningkatan di setiap siklus. Aktivitas belajar siswa di siklus I diperoleh persentase aktivitas belajar siswa dalam proses pembelajaran sebesar $60,36 \%$, pada siklus II diperoleh persentase aktivitas belajar siswa dalam proses pembelajaran sebesar $72,66 \%$, dan pada siklus III diperoleh persentase aktivitas belajar siswa dalam proses pembelajaran sebesar 80,28\% . Hal ini menunjukan bahwa model Discovery Learning dapat meningkatkan aktivitas belajar siswa dalam pembelajaran.

\section{REFERENCES}

Abdulah, A., Mustadi, A., \& Fitriani, W. (2021). PBL-Based Interactive Multimedia in Improving Critical Thinking Skills. JPI (Jurnal Pendidikan Indonesia), 10(1), 136. https://doi.org/10.23887/jpi-undiksha.v10i1.25521.

Arrasyid, H., Jufrida., \& Darmaji. (2017). Aktivitas Dan Hasil Belajar Siswa Dengan Menggunakan Model Pembelajaran Problem Based Learning Berbantuan Lembar Kerja Siswa Pada Materi Kalor Dan Perpindahannya Kelas X SMA PGRI 2 Jambi. Jurnal Edufisika, 2(2), 68-80. https://doi.org/10.22437/edufisika.v5i02.10886.

Arum, T. S., \& Wahyudi, W. (2016). Pengembangan Modul Pembelajaran Tematik Integratif 
Subtema Hubungan Makhluk Hidup Dalam Ekosistem Pendekatan Saintifik Untuk Kelas 5 Sd. Scholaria: Jurnal Pendidikan Dan Kebudayaan, 6(3), 239. https://doi.org/10.24246/j.scholaria.2016.v6.i3.p239-250.

Asta, I. K. R., Agung, A. A. G., \& Widiana, I. W. (2015). Pengaruh Pendekatan Saintifik dan Kemampuan Berpikir Kritis terhadap Hasil Belajar IPA. Mimbar PGSD Undiksha, 3(1), 1-10. https://doi.org/10.23887/jjpgsd.v3i1.5637.

Astiti, N. K. A., Kristiantari, M. G. R., \& Saputra, K. A. (2021). Efektivitas Model Pembelajaran Discovery Learning Dengan Media Powerpoint Terhadap Hasil Belajar IPA Siswa SD. Journal of Education Action Research, 5(3), 409-415. https://doi.org/10.23887/jear.v5i3.36695.

Bahar, M. A., Trisiana, A., \& Handini, O. (2019). Pengaruh Metode Demonstrasi Di Dukung Video Terhadap Hasil Belajar Pembelajaran Tematik Integratif. Jurnal Sinektik, 2(1), 64-76. https://doi.org/10.33061/js.v2i1.2989.

Citrawathi, D. M., Adnyana, P. B., \& Santiasa, M. P. A. (2016). Analisis Kebutuhan Untuk Pengembangan Modul Inkuiri Berbasis Pertanyaan (MIBP) Di SMP. JPI (Jurnal Pendidikan Indonesia), 5(1), 1-11. https://doi.org/10.23887/jpi-undiksha.v5i1.8289.

Estuwardani, N. A., \& Mustadi, A. (2015). Pengembangan Bahan Ajar Modul Tematikintegratif Dalam Peningkatan Karakter Peserta Didik Kelas I Sekolah Dasar. Jurnal Pendidikan Karakter, O(2), 157-172. https://doi.org/10.21831/jpk.v0i2.8620.

Estuwardani, Norayeni Arista, \& Mustadi, A. (2016). Pengembangan Bahan Ajar Modul Tematik-Integratif Dalam Peningkatan Karakter Peserta Didik Kelas I Sekolah Dasar. Jurnal Pendidikan Karakter, O(2), 157-172. https://doi.org/10.21831/jpk.v0i2.8620.

Febryanto, F. N. (2015). Pembelajaran Lay Up Shoot Menggunakan Media Audio Visual Basic Lay Up Shoot Untuk Meningkatkan Hasil Belajar Lay Up Shoot Pada Siswa Kelas Viiia Smp Kanisius Pati Tahun 2013/2014. E-Jurnal Physical Education, Sport, Health and Recreation, 4(1), 1509-1521. https://doi.org/10.15294/active.v4i1.4548.

Hapsyah, D. R., Handayani, R., Marjo, H. K., \& Hanim, W. (2019). Bimbingan Kelompok Dengan Pendekatan Rational Emotive Behavior Theraphy (Rebt) Dalam Meningkatkan Motivasi Belajar. Jurnal Selaras : Kajian Bimbingan Dan Konseling Serta Psikologi Pendidikan, 2(1), 23-33. https://doi.org/10.33541/sel.v2i1.1002.

Indraswati, D., Marhayani, D. A., Sutisna, D., Widodo, A., \& Maulyda, M. A. (2020). Critical Thinking Dan Problem Solving Dalam Pembelajaran Ips Untuk Menjawab Tantangan Abad 21. Sosial Horizon: Jurnal Pendidikan Sosial, 7(1), 12. https://doi.org/10.31571/sosial.v7i1.1540.

Khoeriyah, N., \& Mawardi, M. (2018). Penerapan Desain Pembelajaran Tematik Integratif Alternatif Berbasis Kearifan Lokal untuk Meningkatkan Hasil dan Kebermaknaan Belajar. Mimbar Sekolah Dasar, 5(2), 63. https://doi.org/10.17509/mimbarsd.v5i2.11444.

Legiman. (2015). Penelitian Tindakan Kelas (PTK). LPMP DI Yogyakarta. http://lpmpjogja.kemdikbud.go.id/wp-content/uploads/2015/02/Penelitian-TindakanKelas-PTK-legiman.pdf.

Noviyanti, E., Rusdi, R., \& Ristanto, R. H. (2019). Guided Discovery Learning Based on Internet and Self Concept: Enhancing Student's Critical Thinking in Biology. Indonesian Journal of Biology Education, 2(1), 7-14. https://doi.org/10.31002/ijobe.v2i1.1196.

Pittariawati. (2020). Penggunaan Model Pembelajaran Inside-Outside Circle Untuk Meningkatkan Pemahaman Siswa SMA Kelas XI Pada Materi Teks Prosedur. Jurnal Pendidikan Tambusai, 4(1), 73-81.

Purwanto, M. N. (2017). Psikologi Pendidikan. Remaja Rosda Karya.

Putri, N. M. C. N. M., Ardana, I. K., \& Agustika, G. N. S. (2019). Pengaruh Model 
Discovery Learning Berbantuan Lingkungan Terhadap Kompetensi Pengetahuan IPA Siswa Kelas V. Mimbar PGSD, 7(2), 57-64.

Sahara, R., Mardiyana, \& Sari, R. (2017). Literatur Study: Discovery Learning Teaching Model trough Somatic Auditory Visual Intelectual Approach in Mathematic Teaching. $\quad 4 \quad T h \quad$ ICRIEMS Proceedings, 135-140. http://seminar.uny.ac.id/icriems/sites/seminar.uny.ac.id.icriems/files/prosiding2017/M E20 Rifki Sahara.pdf.

Subiyakto, B., Syaharuddin, S., \& Rahman, G. (2017). Nilai-Nilai Gotong Royong Pada Tradisi Bahaul Dalam Masyarakat Banjar Di Desa Andhika Sebagai Sumber Pembelajaran Ips. Vidya Karya, 31(2), 153-165. https://doi.org/10.20527/jvk.v31i2.3993.

Subudi, I. K. (2021). Peningkatan Aktivitas dan Hasil Belajar Biologi Sebagai Dampak Penerapan Model Pembelajaran Kooperatif Tipe Group Investigation. Journal of Education Action Research, 5(1), 17-25. https://doi.org/10.23887/jear.v5i1.32131.

Sunarsih, S., Rahayuningsih, M., \& Setiati, N. (2020). The Development of Biodiversity Module Using Discovery Learning Based on Local Potential of Wonosobo. Journal of Innovative Science Education, 9(1), $1-11$. https://journal.unnes.ac.id/sju/index.php/jise/article/view/31178.

Ulfah, M., Nurhayati, E., \& Abyati, H. (2019). Pengembangan Media Box of Number Berbasis Tematik untuk Pembelajaran Matematika Permulaan Anak Usia 4-5 Tahun. Al-Athfal Jurnal Pendidikan Anak, 5(2), 151-168.

Wulandari, D. G. R., \& Mustadi, A. (2019). Comparison of Discovery and Inquiry Model: Which Model is More Effective in Natural Science (IPA) Learning? International Journal of Educational Research Review, 4(Special Issue), 711-718. https://doi.org/10.24331/ijere.628710. 